\title{
Z KOLEKCJI DOMOWYCH DO ZBIORÓW PUBLICZNYCH - KSIĘGOZBIORY PISARZY W MUZEUM LITERACKIM KSIĄŻNICY POMORSKIEJ W SZCZECINIE
}

Słowa kluczowe: biblioteka publiczna, kolekcja książek, poeta, archiwum, dedykacja

Keywords: public library, book collections, poet, archives, dedication

\begin{abstract}
FROM PRIVATE TO PUBLIC COLLECTIONS - WRITERS' ASSORTMENTS OF BOOKS IN THE POMERANIAN LIBRARY LITERARY MUSEUM IN SZCZECIN
\end{abstract}

\section{Su m m ary}

The authoress describes the course of relocation of book collections gathered by writers to public library archives using the example of four such collections that made their way to the Pomeranian Library in Szczecin, whose previous owners were: Stefan Flukowski, Zbigniew Herbert, Ludmiła Marjańska and Andrzej Kuśniewicz. The intent of the writers or their heirs was finding a proper place for each particular collection in order to ensure its preservation and further use. The librarians responsible for establishing public collections hoped that the books would be accompanied by manuscripts, personal mail or other keepsakes; or, should that not be the case - that they would bear dedications, autographs, handwritten notes or other signs of the writers' use. The author analyses the contents of these four donations with regard to the aspects mentioned above.

\section{Wprowadzenie}

Księgozbiory, tak jak domy, trwają dłużej niż ich właściciele. Ci ostatni niekiedy jeszcze za życia muszą zmierzyć się z koniecznością rozstania ze swoją kolekcją. Częstym miejscem, w którym bibliofile lub ich spadkobiercy szukają przytuliska dla osieroconych zbiorów, są biblioteki.

W strukturze organizacyjnej Książnicy Pomorskiej im. S. Staszica, największej placówki bibliotecznej na Pomorzu Zachodnim, znajduje się Sekcja Rękopisów - Muzeum Literackie. W jej ramach funkcjonuje w gmachu Książnicy Sala Stefana Flukowskiego - izba o charakterze muzealnym, w której odbywają się konferencje, lekcje biblioteczne i spotkania autorskie, a której przestrzeń wypełniają książki z domowej biblioteczki patrona sali i kilku innych pisarzy. 


\section{Spuścizna po rodzinie Flukowskich}

Stefan Bronisław Flukowski, pisarz i poeta związany z grupą literacką Kwadryga, tłumacz dzieł Anatola France'a, Aleksandra Dumasa czy Paula Éluarda, w 1939 roku wojennym zrządzeniem losu trafił do obozu jenieckiego w Woldenbergu (obecnie Dobiegniew). Spędził tam sześć lat, szczęśliwie jednak przeżył. Także jego żona, Maria Flukowska, przetrwała II wojnę światową. W latach powojennych zamieszkali razem - najpierw w Krakowie, a od 1950 roku w Warszawie - Flukowski chętnie jednak wracał na Pomorze Zachodnie. Zatrzymywał się w Barlinku, gdzie wypoczywał, miał spotkania literackie i zaprzyjaźnił się z członkami Towarzystwa Miłośników Barlinka. Jeden z tamtejszych działaczy-regionalistów, Czesław Paśnik, w 1961 roku założył w swoim mieszkaniu izbę pamiątek regionalnych. Dziesięć lat później udało mu się doprowadzić do powstania Barlineckiego Muzeum Regionalnego w budynku, w którym działała już miejscowa biblioteka publiczna.

Tam właśnie, trzy lata później, 3 czerwca 1974 roku, otwarto Salę Stefana Flukowskiego, w której znalazły się liczne pamiątki, rękopisy, obrazy, rzeźby i księgozbiór pisarza. Przedmioty te zostały przekazane przez wdowę po Stefanie, Marię, jak jednak możemy przeczytać w opisach tej pierwszej sali imienia pisarza - stało się to zgodnie $\mathrm{z}$ wolą zmarłego ${ }^{1}$. Flukowski dostał ataku serca i umarł w roku 1972 podczas spotkania autorskiego w bibliotece miejskiej w Świnoujściu. Być może więc rzeczywiście jeszcze za życia rozmawiał o przekazaniu swojego archiwum otwartej rok wcześniej barlineckiej placówce. Tym bardziej, że spodziewał się, iż jego rodzina wymrze bezpotomnie. Maria i Stefan nie mieli bowiem własnych dzieci. Mieszkali z córką Marii z pierwszego małżeństwa, Haliną Leszczyńską, która nie założyła własnej rodziny. To właśnie te dwie kobiety - żona i pasierbica - po śmierci pisarza zadecydowały o losie rodzinnej spuścizny, która obejmowała dużo więcej niż tylko domową bibliotekę czy nawet archiwum twórcze Flukowskiego.

Niezwykła rodzina miała bowiem liczne kontakty ze środowiskiem artystycznym. Po wojnie Maria Flukowska pełniła funkcję sekretarza Xawerego Dunikowskiego, z którym obydwoje z mężem zaprzyjaźnili się i spędzali także czas wolny. Przyjaźnili się również z małżeństwem artystów-plastyków Marią i Stanisławem Dawskimi, nawiązali serdeczne relacje z wdową po Witkacym, Jadwigą. W efekcie do domowego archiwum Flukowskich trafiły dokumenty i pamiątki związane z Dunikowskim, obrazy malarzy skupionych wokół wrocławskiej Akademii Sztuk Pięknych, pamiątki i archiwalia Jadwigi Witkiewiczowej. W spuściźnie Dunikowskiego znalazły się nie tylko papiery osobiste rzeźbiarza,

${ }^{1}$ Kazimiera Zdzisława Szymańska, Muzea literackie w Polsce (Częstochowa: Wydaw. WSP, 1995), 64. 
ale także jego rzeźby i szkice ${ }^{2}$. Po Witkiewiczowej zostały m.in. portrety Witkacego, ponad 1200 listów pisarza do żony, rodzinne fotografie. Jadwiga Witkiewiczowa, spisując swoją ostatnią wolę, dała Marii Flukowskiej dyspozycję, by listy od męża przekazać do wrocławskiego Ossolineum lub Biblioteki Narodowej, a to, co uzna za stosowne z pamiątek i „papierów” po Witkacym, do jakiejś bliżej nieokreślonej biblioteki ${ }^{3}$. Ostatecznie wszystko, wraz z całą artystyczną spuścizną i biblioteką domową Flukowskich, trafiło do Książnicy Pomorskiej w Szczecinie.

Nim to jednak nastąpiło, przez blisko półtora roku pamiątki po Stefanie Flukowskim były zdeponowane w izbie muzealnej w Barlinku. Być może, zdawszy sobie sprawę z wielkiej wartości posiadanych zasobów i stwierdziwszy, że wybrane dla nich miejsce (prowincjonalne muzeum) jest nieadekwatne do ich znaczenia dla kultury, Flukowska z czasem zmieniła zdanie, zwłaszcza że nadarzyła się po temu okazja. Była nią wystawa poświęcona Stefanowi Flukowskiemu, zorganizowana jesienią 1975 roku przez bibliotekę w Szczecinie z okazji jubileuszu Szczecińskiego Oddziału Związku Literatów Polskich ${ }^{4}$. Na potrzeby tej ekspozycji przewieziono związane z Flukowskim muzealia z Barlinka do Szczecina. W drugą stronę nigdy już nie odjechały. Do dziś w Muzeum Regionalnym w Barlinku pozostało tylko to, co wówczas nie zostało przetransportowane - krzesło, mały sekretarzyk i fotel w pasiastej tapicerce.

Nie trzeba podkreślać, że w opisanej spuściźnie Flukowskich - której przekazanie przez wdowę po pisarzu zadecydowało o organizacji w Książnicy Pomorskiej kilka lat później odrębnej agendy: Sekcji Rękopisów - Muzeum Literackiego $^{5}$ - księgozbiór nie był najbardziej znaczącą częścią. Z atrakcyjności tego archiwum zdawano sobie sprawę także w innych ośrodkach. Ujawnia to zachowana korespondencja Flukowskiej, w której znajduje się brulion listu adresowany do I sekretarza KW PZPR w Toruniu, Zygmunta Najdowskiego, późniejszego ministra kultury i sztuki ${ }^{6}$. Z treści listu wynika, że Maria Flukowska otrzymała od Najdowskiego propozycję przyjęcia pamiątek po Stefanie Flukowskim przez toruńską bibliotekę miejską, dzisiejszą Książnicę Kopernikańską.

${ }^{2}$ Pewien wgląd w tę spuściznę daje katalog wystawy zorganizowanej w 1999 r. przez Książnicę Pomorską we współpracy z Muzeum im. Xawerego Dunikowskiego w Królikarni; vide Xawery Dunikowski, ed. Joanna Torchała (Szczecin: Książnica Pomorska, 2000).

${ }^{3}$ Testament Jadwigi Witkiewiczowej, in Archiwum Marii $i$ Stefana Flukowskich (rękopis), Książnica Pomorska w Szczecinie, sygn. Inwakc. 824, k. 1r.

${ }^{4}$ „Kronika działalności bibliotek i Stowarzyszenia Bibliotekarzy Polskich”, Bibliotekarz Zachodniopomorski, no. 4 (1975): 83-84.

${ }^{5}$ Geneza i funkcje tej agendy zostały bliżej opisane przez Cecylię Judek; vide eadem, „Zbiory specjalne", in Od Stadtbibliothek do Ksiażnicy Pomorskiej 1905-2005, ed. Hanna Niedbał et al. (Szczecin: Książnica Pomorska, 2005), 91-94.

${ }^{6}$ List Marii Flukowskiej do I sekretarza KW PZPR Zygmunta Najdowskiego, in Archiwum Marii i Stefana Flukowskich (rękopis), Książnica Pomorska w Szczecinie, sygn. Inwakc. 2133. 
W odpowiedzi napisała, że po wahaniu i dokładnym rozważeniu sprawy zdecydowała się jednak na Szczecin. O postanowieniu tym przesądziło kilka czynników. Pierwszym, jaki wymienia Flukowska, jest zadeklarowana przez bibliotekę szczecińską chęć zgromadzenia kolekcji związanej z członkami grupy poetyckiej Kwadryga, której współzałożycielem i członkiem był Stefan Flukowski. Spośród innych kwadrygantów Flukowska wymienia Konstantego Ildefonsa Gałczyńskiego, Stanisława Marię Salińskiego i Ninę Rydzewską - na marginesie wypada zaznaczyć, że materiały związane z tymi twórcami w większym lub mniejszym wyborze (rękopisy, książki, dokumenty, muzealia) rzeczywiście trafiły do Książnicy Pomorskiej. Flukowska pisze, że stworzenie w Szczecinie „ośrodka propagandowego dla Kwadrygi” jest celem o dużym znaczeniu, gdyż w opinii publicznej twórczość kwadrygantów jest niżej oceniana niż członków grupy poetyckiej Skamander i to właśnie skamandryci, mimo swego „oportunizmu i płycizny”, utrzymują się, w opinii Flukowskiej, „w pozycji zwycięzców”. Warto nadmienić, że w okresie poprzedzającym małżeństwo z Flukowskim Maria była w nieformalnym związku z Jerzym Liebertem, poetą, który pozostawał w bardzo przyjacielskich relacjach z członkami Skamandra i publikował na łamach ich czasopisma. Po przedwczesnej śmierci tego poety była zaangażowana w zabezpieczenie dziedzictwa po nim, a ocalałe $\mathrm{z}$ wojennej pożogi liebertiana także znalazły się w jej domowym archiwum ${ }^{7}$, co dodaje nieco smaku przytoczonej wyżej wypowiedzi.

Jako kolejny argument na rzecz wyboru Szczecina podaje Flukowska znaczenie spuścizny po mężu dla samego miasta, w którym, jak sądzi, może się dzięki temu zacząć rozwijać zainteresowanie dla „poezji i pisarstwa postępowego”. Wskazuje przy tym na bliskość granicy z Niemcami, narodem, który stoi na wysokim poziomie cywilizacyjnym oraz kulturalnym. Podkreśla w końcu znaczenie Szczecina i regionu dla zmarłego pisarza, który spędził na tych terenach lata okupacji, a później chętnie je odwiedzał, wypoczywał tam, ale i miał liczne spotkania autorskie i, jak pisze, „znalazł tu dopiero uznanie i wielu czytelników” oraz „gorąco pokochał to miasto”.

W tych okolicznościach w maju 1977 roku w bibliotece szczecińskiej, w oparciu o zbiory przekazane wcześniej przez wdowę po pisarzu do Muzeum im. S. Flukowskiego w Barlinku, została otwarta Sala Stefana Flukowskiego. W przekazanej spuściźnie znalazły się:

- licząca ponad 3 tys. woluminów biblioteka domowa Flukowskich (przechowywana w specjalnie obstalowanych szafach);

- spuścizna rękopiśmienno-archiwalna, w skład której, oprócz archiwum Flukowskich, weszły też wspomniane archiwalia Witkiewiczów, Xawerego Dunikowskiego, Jerzego Lieberta;

${ }^{7}$ Opisuje je Cecylia Judek, „Jerzy Liebert i Maria Leszczyńska. Liebertiana w Książnicy Pomorskiej w Szczecinie”, Pogranicza, no. 6 (1999): 60-64. 
- obiekty muzealne, które złożyły się na wystrój sali (drobne meble, kolekcje rzemiosła artystycznego, przedmioty użytkowe, zbiory dzieł sztuki z warszawskiego mieszkania Flukowskich, obrazy i rzeźby Dunikowskiego, portrety Witkacego). Nie obyło się jednak bez walki. W piśmie ${ }^{8} \mathrm{z}$ dn. 28 października $1980 \mathrm{r}$. kierownik muzeum barlineckiego Józef Krupa, a w kolejnym, z dn. 22 maja 1981 r., naczelnik miasta i gminy w Barlinku Julian Sawaściuk wzywali bibliotekę do zwrotu „księgozbioru, osobistych przedmiotów i pamiątek oraz dzieł sztuki po Stefanie Flukowskim”, będących „w dalszym ciągu własnością Muzeum Regionalnego w Barlinku”. „Powyższy fakt - czytamy dalej w liście podpisanym przez Sawaściuka - wynika stąd, że zbiory zostały przekazane protokolarnie przez P. Marię Flukowską ww. muzeum. Natomiast Wasza biblioteka nie dysponuje żadnym dokumentem, który sankcjonowałby przekazanie eksponatów z Barlinka do Szczecina"10.

Autor pisma nie wiedział jednak, że Maria Flukowska, w 1981 roku już nieżyjąca, zdążyła dać na piśmie wyraz swojej zmienionej woli ${ }^{11} .25$ września 1976 roku, a więc jeszcze przed zorganizowaniem Sali Stefana Flukowskiego w szczecińskiej bibliotece, której otwarcia zresztą nie doczekała, podpisała swoisty „dokument przekazania”. W odręcznej notatce zaadresowanej do dyrektora biblioteki Stanisława Krzywickiego, napisała:

Zgodnie z naszymi ustaleniami pragnę przekazać Bibliotece im. S. Staszica w Szczecinie zbiory S. i M. Flukowskich celem urządzenia stałej ekspozycji poświęconej Poecie. Jednocześnie proszę o udzielenie pomocy w przygotowaniu dokładnych spisów wszystkich eksponatów: rękopisy, listy, dzieła sztuki, książki i inne przedmioty. Część eksponatów pozostanie na prawach depozytu do czasu zakupienia przez Bibliotekę na zasadzie porozumienia stron. Z uwagi na konieczność zachowania całości zbiorów nie mogą one być przekazane do innych instytucji, a dysponować nimi winien i może jedynie Pan Stanisław Witold Krzywicki ${ }^{12}$.

Być może na fali przywołanej wyżej korespondencji z instytucjami barlineckimi, 5 czerwca 1981 roku biblioteka podpisała oficjalny akt przekazania zbiorów $^{13} \mathrm{z}$ jedyną już wówczas żyjącą spadkobierczynią Flukowskich, Haliną Leszczyńską. W piśmie tym Leszczyńska podkreśliła, że działa zgodnie z wolą matki,

${ }^{8}$ Pismo Józefa Krupy o sygn. M.R.B./0/40/1980 z dn. 28.10.1980, in Teka zagadnieniowa „Sala Stefana Flukowskiego” (rękopis), Książnica Pomorska w Szczecinie, bez sygn.

${ }^{9}$ Pismo Juliana Sawaściuka o sygn. SAiO-IX-415-18/81 z dn. 22.05.1981, in Teka zagadnieniowa „Sala Stefana Flukowskiego” (rękopis), Książnica Pomorska w Szczecinie, bez sygn.

${ }^{10}$ Ibidem.

${ }^{11}$ Pismo Marii Flukowskiej do Stanisława Krzywickiego z dn. 25.09.1976, in Teka zagadnieniowa „Sala Stefana Flukowskiego” (rękopis), Książnica Pomorska w Szczecinie, bez sygn.

${ }^{12}$ Ibidem.

${ }^{13}$ Akt przekazania Bibliotece Głównej im. Stanisława Staszica w Szczecinie zbiorów po Stefanie i Marii Flukowskich przez Halinę Leszczyńską, in Teka zagadnieniowa „Sala Stefana Flukowskiego” (rękopis), Książnica Pomorska w Szczecinie, bez sygn. 
Marii Flukowskiej, i określiła warunki, z jakich powinna się wywiązać biblioteka, przejmując tę spuściznę. Pierwszym z nich jest organizacja Sali Stefana Flukowskiego, co, jak wiemy, stało się kilka lat wcześniej, w drugim - zastrzega „,zachowanie charakteru” tejże sali „na czas wieczysty”, stawia ponadto warunek, by utrzymać „nazwę Sali Stefana Flukowskiego oraz nie przekazywać ani w części, ani w całości darowanych zbiorów innej instytucji”"14.

Przekazany wraz z archiwum domowym Flukowskich księgozbiór, przechowywany w Sali Stefana Flukowskiego, liczy ponad trzy tysiące tomów. Jest to interesująca biblioteka ujawniająca humanistyczny charakter zainteresowań pisarza. W latach 70., kiedy kolekcja trafiła do biblioteki, znaczenie miał z pewnością fakt, że zawierała książki wydane za granicą, do których w czasach PRL był utrudniony dostęp, a ich ceny - bardzo wysokie. W księgozbiorze pisarza znalazły się dzieła po francusku, rosyjsku, angielsku, a nawet kilka książek chińskich. Dziś jednak największe znaczenie mają zawarte w tych książkach dedykacje ${ }^{15}$. Jedną z najcenniejszych jest autograf Czesława Miłosza w drugim wydanym przed wojną tomiku poetyckim Trzy zimy (Wilno 1936). W księgozbiorze odnajdziemy także wpisy innych zasłużonych i sławnych pisarzy, takich jak Zofia Nałkowska, Julian Przyboś, Jerzy Szaniawski, Marian Brandys, Jerzy Putrament, Władysław Broniewski. Są tu również dedykacje od kolegów kwadrygantów - Władysława Sebyły i Konstantego Ildefonsa Gałczyńskiego. Znakiem serdecznych relacji z obydwojgiem małżonków są wpisy Jadwigi Witkiewiczowej w powojennych wydaniach dzieł Witkacego. Do biblioteki Flukowskich przeniknęły również przedwojenne utwory Witkacego z pięknymi wpisami dla żony, „ukochanej Nineczki”.

Ciekawym śladem dawnej zażyłości jest także autograf Henryki Wandy Łazowertówny, poetki polsko-żydowskiej, która zginęła w Treblince w 1942 roku. Dedykacja dla Stefana Flukowskiego wpisana została do jej debiutanckiego tomiku poetyckiego Zamknięty pokój (Warszawa 1930). Brzmi następująco: „Zgodnie z prośbą o «namiętną» dedykację - i na wzór pewnej, o której mi Pan wspominał - wszystkie «serca», w owym tomie zawarte, ofiarowuje z uściskiem dłoni - H. Łazowertówna. Warszawa, d. 19/IV 1931 r.”. W momencie dokonywania wpisu autorka miała zaledwie 22 lata, Stefan Flukowski - 29, ale nie był jeszcze żonaty z Marią. Być może zdanie to jest pamiątką po jakiejś wzajemnej fascynacji, rodzącej się między dwojgiem młodych twórców ${ }^{16}$.

${ }^{14}$ Ibidem.

${ }^{15}$ Bliższa charakterystyka księgozbioru pod tym kątem vide Cecylia Judek, „Ciekawsze rękopiśmienne dedykacje autorskie w księgozbiorze Marii i Stefana Flukowskich”, Bibliotekarz Zachodniopomorski, no. 2-3 (1984): 74-83; cf. Barbara M. Kownacka, „Dedykacje w księgozbiorze Stefana i Marii Flukowskich”, in Stefan Flukowski i kult nowoczesności, ed. Jerzy Madejski, Beata M. Wolska (Szczecin: Książnica Pomorska, 2015), 69-90.

${ }^{16}$ Więcej na ten temat vide Cecylia Judek, „Przyjaźnie Stefana Flukowskiego”, in Stefan Flukowski i kult..., 45-49. 
Pozostałe księgozbiory pisarzy, włączone do zasobów Muzeum Literackiego Książnicy Pomorskiej i eksponowane w Sali Stefana Flukowskiego, nie są tak zasobne jak biblioteka patrona miejsca.

\section{Księgozbiór Anny i Andrzeja Kuśniewiczów}

Podobnie jak w przypadku biblioteki Flukowskich, także księgozbiór domowy Andrzeja Kuśniewicza został przekazany Książnicy Pomorskiej na mocy decyzji spadkobierców, a nie samego pisarza. Andrzej Kuśniewicz, prozaik, eseista, poeta, redaktor „Miesięcznika Literackiego”, zmarł w 1993 roku w Warszawie. Wdowa po pisarzu, Anna Lechicka-Kuśniewicz, także pisarka - publicystka i satyryczka - przeżyła męża o 10 lat. To właśnie z nią po śmierci jej męża ówczesny dyrektor Książnicy Pomorskiej, Stanisław Krzywicki, osoba znana i rozpoznawalna w kręgach twórczych, uzgodnił ewentualne przejęcie przez bibliotekę szczecińską materiałów po zmarłym. Niestety, nie dysponujemy dziś żadną dokumentacją ukazującą kulisy tych ustaleń, gdyż wszystkie rozmowy na ten temat miały przebieg bezpośredni lub telefoniczny. Potwierdzają to jednak słowa samego Krzywickiego w wywiadzie dla „Gazety Wyborczej” z dn. 12.03.2003 r.: „Była zainteresowana [Anna Lechicka-Kuśniewicz - A.B.] przekazaniem archiwum męża jakiejś dużej placówce [...]. Kiedy się o tym dowiedziałem, odwiedziłem ją kilkakrotnie i zaproponowałem, aby tą placówką była nasza Książnica. Kandydatów było wielu. A pani Kuśniewiczowa przystała na moją prośbę" 17 .

Księgozbiór nie został jednak przekazany za życia wdowy po Kuśniewiczu. Anna Lechicka przekazała informację o propozycji Krzywickiego swojej krewnej, Marii Kobierzyckiej-Maciąg, i to ona po śmierci Lechickiej skontaktowała się $\mathrm{z}$ biblioteką.

Jak się okazało, wcześniej zaproponowała spuściznę po Kuśniewiczach warszawskiemu Muzeum Literatury im. A. Mickiewicza. Wydelegowana do Warszawy pracownica Muzeum Literackiego Książnicy Pomorskiej, Jolanta Liskowacka, zastała więc na miejscu, w maleńkim mieszkaniu Kuśniewiczów, już tylko te materiały, którymi nie była zainteresowana placówka warszawska. Księgozbiór, za zgodą krewnych, był dodatkowo przepatrzony i uszczuplony o pozycje, które zainteresowały innych odwiedzających to mieszkanie. Mimo to zastane materiały okazały się na tyle interesujące, że zadecydowano o przewiezieniu ich do Szczecina.

Rękopisów było niewiele, bo Kuśniewicz pracował na maszynie, a maszynopisy wysyłał do wydawnictw. Mimo to znalazło się trochę kart maszynopisów różnych wypowiedzi pisarza, rodzinna korespondencja i fotografie, papiery osobiste,

${ }^{17}$ Ewa Podgajna, „Maszyna, listy i książki: pamiątki po Andrzeju Kuśniewiczu w Szczecinie”, Gazeta Wyborcza (12.03.2003): 4. 
odznaczenia, dyplomy, legitymacje, a także różne zgromadzone w domowym archiwum dokumenty życia społecznego: zaproszenia, katalogi wystaw, wizytówki, wycinki prasowe i drobne druki dotyczące Andrzeja Kuśniewicza ${ }^{18}$. Przekazano także kilka prac plastycznych ${ }^{19}$, w tym portret cesarza Franciszka Józefa wraz z małżonką, który był prezentem dla Kuśniewicza od Pawła Jasienicy i zawiera odręczną dedykację tego ostatniego.

Główny ślad po pisarzu w zasobach Muzeum Literackiego stanowi jego niewielki (213 woluminów) księgozbiór. Charakterystyczna jest w nim zwłaszcza obecność książek w językach obcych, przede wszystkim niemiecko- i francuskojęzycznych, które Kuśniewicz kupował bądź otrzymywał w czasie swoich licznych podróży. Bogato są też reprezentowane edycje dzieł pisarza w przekładach, zwłaszcza różnojęzyczne wydania powieści Król Obojga Sycylii. Interesujący jest zbiór utworów Josepha Conrada Korzeniowskiego ${ }^{20} \mathrm{w}$ edycjach polskich, opublikowanych w latach 20. i 30. XX wieku. Są też książki ważne dla pisarza - Doktor Faustus Tomasza Manna, powieści ulubionego Iwaszkiewicza i poezje Tuwima ${ }^{21}$. Dedykacji jest zaledwie kilka, np. od Hanny Olędzkiej, tłumaczki powieści $\mathrm{Abel}$ autorstwa Marthe Meyer, francuskiej pisarki i profesora filozofii w Bejrucie. Jeden z tłumaczy awangardowej powieści Roberta Musila pt. Człowiek bez wartości, nawiązując do powieści Kuśniewicza z cyklu galicyjskiego, napisał: „Panu Andrzejowi Kuśniewiczowi, który chyba jak nikt inny zrozumiał czar umierającej Cekanii, zachwycony jego książkami Krzysztof Radziwiłł 4/VII 71”.

W Sali Stefana Flukowskiego stoi także maszyna do pisania marki „Optima” i sekretarzyk z warszawskiego mieszkania Kuśniewiczów, a w nim pamiątki po pisarzu - zegarek na bransolecie, drewniana szkatułka, etui na okulary.

\section{Księgozbiór Zbigniewa Herberta}

Zupełnie inną historię przybycia do biblioteki ma księgozbiór Zbigniewa Herberta. To sam poeta podjął decyzję o przekazaniu go Książnicy Pomorskiej, kiedy w roku 1992, likwidując swe paryskie mieszkanie, przypomniał sobie felieton, którego wysłuchał w radiu Wolna Europa dwa lata wcześniej. Była to wypowiedź prof. Andrzeja Sulikowskiego, polonisty rodem z Krakowa, związanego

\footnotetext{
${ }^{18}$ Archiwum Andrzeja Kuśniewicza (rękopis), Książnica Pomorska w Szczecinie, sygn. Inwakc. 3061-3066.

${ }^{19}$ Wszystkie (15 szt.) trafiły do Oddziału Sztuki Książnicy Pomorskiej.

${ }^{20}$ Są to książki wydane między 1923 a 1935 r. o sygn.: NS 230868; NS 230851; NS 230871, NS 230870, NS 230869.

${ }^{21}$ Opisuje je wszystkie Andrzej Kuśniewicz w swojej książce Moja historia literatury (Warszawa: Państwowy Instytut Wydawniczy, 1980).
} 
następnie ze Szczecinem, w której przekazał on apel pracownicy Książnicy Pomorskiej, Barbary Arsoby, o przekazywanie bibliotece książek. Poeta podjął wówczas decyzję o spakowaniu części swoich zbiorów w paczkę i przekazaniu jej - za pośrednictwem Instytutu Polskiego w Paryżu - na adres biblioteki. Rzecz całą objaśnił w dołączonym liściku, adresowanym do B. Arsoby: „Wielce Szanowna Pani, usłyszawszy w radio apel o przesłanie Książnicy, którą Pani tak dzielnie się opiekuje, i korzystając z pomocy Pana Bogusława Sonika [dyrektora Instytutu Polskiego - uzup. A.B.], pozwalam sobie przesłać parę książek polskich wydanych na emigracji i parę obcojęzycznych”22. Owych „parę książek" wypełniło, jak wynika z korespondencji na ten temat, trzy kartony ${ }^{23}$. Kolejne książki, których łącznie trafiło do biblioteki około 800 woluminów, przesyłała żona poety, Katarzyna Herbertowa, już z Warszawy. Na przekazany księgozbiór złożyły się liczne tomiki poezji samego Herberta, w tym jego dzieła wydane za granicą i w drugim obiegu, a także poetyckie zbiorki innych twórców, prace z zakresu literaturoznawstwa, teorii literatury, historii sztuki, filozofii. Na wielu egzemplarzach książek widnieje rękopiśmienny wpis własnościowy poety, w niektórych są ponadto poczynione jego ręką podkreślenia i zapiski.

W wielu książkach znajdują się dedykacje. Te od przyjaciół są często wspólne - dla obydwojga małżonków - jak np. w tomiku $Z$ podróży, ze snu, z umierania Wiktora Woroszylskiego (Poznań 1992), gdzie oprócz dedykacji: „naszym drogim Zbigniewowi i Kasi”, zamieścił autor jeszcze okolicznościowy wiersz pt. Morze.

Szczególnym rodzajem notatek poety są wpisane do tomików innych autorów, niekiedy debiutantów, ich adresy, najpewniej spisane z kopert, w których przyszły książki. Widocznie planował Herbert odpowiedzieć na otrzymaną przesyłkę, może zrecenzować przesłane próby poetyckie. O tym, że działo się tak w istocie, zaświadcza zachowany w Książnicy Pomorskiej, w archiwum po zmarłym przedwcześnie poecie szczecińskim Henryku Banasiewiczu, krótki list Herberta. Dziękując Banasiewiczowi za przesłany tomik Pieśni miłości i pocieszenia, Herbert pisze: ,„[...] przeczytałem go uważnie z wielkim dla siebie pożytkiem, starając się dzięki Panu zaczerpnąć coś z mądrości Wschodu. Zadziwiające i piękne"24.

${ }^{22}$ List Zbigniewa Herberta do Barbary Arsoby, in Materiaty zwiazane z przekazaniem daru Zbigniewa Herberta dla Ksiąznicy Szczecińskiej (rękopis), Książnica Pomorska w Szczecinie, sygn. Inwakc. 1944, k. 1.

${ }^{23}$ List Stanisława Krzywickiego do Bogusława Sonika, in Materiały zwiazane z przekazaniem daru Zbigniewa Herberta dla Książnicy Szczecińskiej (rękopis), Książnica Pomorska w Szczecinie, sygn. Inwakc. 1944, k. 3.

${ }^{24}$ Pisze o tym Cecylia Judek - vide Tadeusz Zwilnian-Grabowski, Cecylia Judek, „Dwugłos o Zbigniewie Herbercie”, Bibliotekarz Zachodniopomorski, no. 3 (1998): 42-45. 
Nawiązane pod wpływem przekazanej darowizny sympatyczne relacje między Książnicą a poetą były w kolejnych latach podtrzymywane. W 1993 roku zorganizowano wystawę ukazująca dary poety dla biblioteki. Z tej okazji Herbert przysłał telegram, w którym napisał m.in.: „Cieszę się bardzo, że mój skromny dar będzie mógł służyć czytelnikom, z którymi łączy mnie wspólne umiłowanie książek" "25. Rok później, w 1994 roku, z okazji 70. urodzin autora Pana Cogito, z inicjatywy Książnicy Pomorskiej opracowano okolicznościowy tomik poetycki Trzeba śnić cierpliwie, w którym znalazły się wiersze poetów szczecińskich. Wówczas Herbert również zareagował, przesyłając ciepłe w tonie podziękowania każdemu z zaangażowanych w przedsięwzięcie. W 1997 roku, w ostatnim liście przesłanym do dyrektora Krzywickiego, pisał: „Komplementy, którymi mnie Pan obsypuje, są ponad miarę moich zasług, ale nie będę ukrywał, że przywiązałem się do Książnicy. Coś tam nawet zacząłem grzebać w nad wyraz skromnych archiwach, ale to musi jeszcze potrwać, ponieważ nie poruszam się o własnych siłach”26.

Przekazanie Książnicy archiwum twórczego nigdy nie nastąpiło, jednak - na mocy decyzji samego poety, a potem wdowy po nim, Katarzyny Herbertowej - w zbiorach rękopiśmiennych znalazły się różne materiały odnalezione w ofiarowanych książkach: korespondencja, drobne zapiski, wycinki prasowe, odbitki artykułów $^{27}$. W 2002 roku Katarzyna Herbertowa i siostra zmarłego, Halina Herbert-Żebrowska, uczestniczyły w nadaniu imienia Zbigniewa Herberta sali, w której mieści się obecnie Czytelnia Zbiorów Specjalnych Książnicy Pomorskiej ${ }^{28}$.

\section{Księgozbiór Ludmiły Marjańskiej}

Podobne do Herbertowych powody przekazania księgozbioru Książnicy Pomorskiej miała Ludmiła Marjańska, pisarka znana najbardziej z własnych tomików poetyckich i tłumaczeń poezji angielskiej, która po śmierci męża, w 2003 roku, likwidowała mieszkanie przy ul. Raszyńskiej w Warszawie i przenosiła się do mniejszego, przy ul. Królowej Marysieńki. Propozycja, by książki z domowej biblioteczki znalazły się w szczecińskiej Książnicy, napłynęła od samej poetki. W liście do Stanisława Krzywickiego z 7 sierpnia 2003 r. napisała:

${ }^{25}$ Telegram od Zbigniewa Herberta, in Materiaty zwiazane z przekazaniem daru Zbigniewa Herberta dla Książnicy Szczecińskiej (rękopis), Książnica Pomorska w Szczecinie, sygn. Inwakc. 1944, k. 10.

${ }^{26}$ List Zbigniewa Herberta do Stanisława Krzywickiego, in Materiaty zwiazane z przekazaniem daru Zbigniewa Herberta dla Ksiąznicy Szczecińskiej (rękopis), Książnica Pomorska w Szczecinie, sygn. Inwakc. 1944, k. 13.

${ }^{27}$ Archiwum Zbigniewa Herberta (rękopis), Książnica Pomorska w Szczecinie, sygn. Inwakc. 1942, 2728, 2949.

${ }^{28}$ Jolanta Liskowacka, „«...uwierzyliśmy zbyt łatwo, że piękno nie ocala...» Zbigniew Herbert w Książnicy Pomorskiej”, Bibliotekarz Zachodniopomorski, no. 2-3 (2002): 66-75. 
„Szanowny Panie Dyrektorze, dawno temu, podczas mojego pobytu w Szczecinie, dowiedziałam się od Pana, że Książnica gromadzi książki z autografami. Jestem w przededniu przeprowadzki do mniejszego mieszkania i musze rozdać część mojej biblioteki (w tym sporo tomików poetyckich z dedykacjami). Byłabym wdzięczna za informację, czy Książnica skłonna jest i czy ma jeszcze miejsce na książki” ${ }^{29}$.

Ze Szczecinem, Książnicą Pomorską i miejscowym środowiskiem literackim, a zwłaszcza z poetką Heleną Raszką, zaprzyjaźniła się Marjańska prawdopodobnie w latach 1993-1996, kiedy pełniła funkcję prezeski Stowarzyszenia Pisarzy Polskich, a szczeciński oddział SPP również był w tym czasie bardzo aktywny.

Przekazane w 2003 roku książki składają się na najmniejszy z księgozbiorów pisarzy w zbiorach tutejszego Muzeum Literackiego - liczy zaledwie 151 woluminów. Są to niemal wyłącznie tomiki wierszy, najczęściej ofiarowane przez samych autorów lub przyjaciół, którzy chcieli takim prezentem sprawić radość poetce.

Przegląd tomików ukazuje nie tylko zainteresowania Marjańskiej - jest tu niemal wyłącznie współczesna poezja polska - ale i odkrywa krąg jej bliskich i dalszych znajomych. Niekiedy lektura dedykacji zawartych w poszczególnych tomikach obrazuje ewolucję wzajemnych relacji, jak w przypadku Julii Hartwig, którą łączyło z Marjańską szczególnie wiele - obie poetki i tłumaczki anglojęzycznej poezji, w podobnym wieku, mieszkanki Warszawy. W pierwszym tomiku ofiarowanym Marjańskiej przez Hartwig, w roku 1978, widnieje jeszcze formuła „Drogiej Pani Ludmile”, w dalszych tomach jest już „Drogiej Ludmile”, a ton wpisów jest bardzo serdeczny ${ }^{30}$.

Spośród innych postaci życia literackiego, których dedykacje znajdziemy w księgozbiorze Marjańskiej, warto wymienić przede wszystkim Zbigniewa Herberta, który pozostawił w ofiarowanych zbiorkach ciepłe słowa. Przyjazne stosunki łączyły Marjańską także z twórczynią literatury młodzieżowej, Danutą Bieńkowską. Serdeczne zawodowe kontakty $-\mathrm{z}$ dwojgiem poetów i prozaików, których los rzucił do USA, Anną Frajlich i Henrykiem Grynbergiem. W książkach Marjańskiej, tak jak i w księgozbiorze Herberta, znaleziono trochę archiwaliów. Złożyły się one na trzy jednostki, włączone, za zgodą poetki, do zbiorów rękopiśmiennych ${ }^{31}$. Znalazły się w nich karty pocztowe, pojedyncze listy, dokumenty życia społecznego, wycinki prasowe.

${ }^{29}$ List Ludmiły Marjańskiej do Stanisława Krzywickiego z 7.08.2003, in Materiaty dotyczace księgozbioru Marjańskiej (rękopis), Książnica Pomorska w Szczecinie, bez sygn.

${ }^{30}$ Więcej na temat księgozbioru Marjańskiej i dedykacji w nim vide Jolanta Liskowacka, „Księgozbiór Ludmiły Marjańskiej (w zbiorach Książnicy Pomorskiej w Szczecinie)”, in O Ludmile Marjańskiej. Szkice, interpretacje, wspomnienia, ed. Elżbieta Hurnikowa, Iwona Skrzypczyk-Gałkowska (Częstochowa: Muzeum Częstochowskie, 2015), 143-155.

${ }^{31}$ Archiwum Ludmiły Marjańskiej (rękopis), Książnica Pomorska w Szczecinie, sygn. Inwakc. 3088, 3164, 3458. 
Co ciekawe, swe pozostałe archiwalia Marjańska postanowiła przekazać Bibliotece Publicznej im. dr. Władysława Biegańskiego w rodzinnej Częstochowie ${ }^{32}$. Miasto to i bibliotekę odwiedzała regularnie, począwszy od 1987 roku, i promowała tam swoje kolejne książki. Podczas pobytu w 2004 roku uzgodniła przekazanie swego archiwum twórczego właśnie tej placówce. Na zbiór ten, liczący ponad 100 jednostek rękopiśmiennych, złożyły się m.in. rękopisy i maszynopisy poezji, prozy i tłumaczeń, korespondencja, pamiątki z wyjazdów zagranicznych i krajowych, kolekcje wycinków prasowych itd.

Historie czterech pisarskich księgozbiorów przechowywanych w Sali Stefana Flukowskiego Książnicy Pomorskiej ukazują, że dążeniem ich właścicieli lub spadkobierców była każdorazowo chęć znalezienia dobrego, właściwego i bezpiecznego miejsca dla gromadzonych - nieraz przez lata - kolekcji. W polskiej kulturze książek, podobnie jak jedzenia, raczej się nie wyrzuca. Kiedy drogi kolekcjonera i kolekcji muszą sie rozejść, szuka się dla niej bezpiecznego schronienia, jak dla czworonoga, z którym trzeba, choć żal, się rozstać...

Bibliotekarze, przyjmując od pisarzy książki do zbiorów publicznych (które przecież także są kształtowane z określoną intencją), zwykle liczą na coś więcej niż tylko materiały drukowane. Mają nadzieję, że będą im towarzyszyć rękopisy, papiery osobiste, pamiątki, a nawet jeśli będą to jednak wyłącznie książki - że będą w nich dedykacje, autografy, ślady lektury właściciela. Decyzjom bibliotekarzy o zatrzymaniu kolekcji w jednym miejscu, bez rozpraszania jej po różnych magazynach i agendach, przyświeca zwykle dodatkowo nadzieja, że może znajdą się badacze, którzy będą ją chcieli badać w takim właśnie, całościowym stanie. Taką nadzieję, choć w nieco innym kontekście, wyraził także Andrzej Kuśniewicz, opisując własny księgozbiór: „Zapewne, można spytać, kogo obchodzi zawartość mojej biblioteki. Tak, na pewno, lecz wedle rachunku prawdopodobieństwa, stosując prawo wielkich liczb, zawsze się ktoś taki znajdzie, komu coś się przypomni, trafi do przekonania, spowoduje bodaj krótką radość lub wywoła wesołość"33.

\section{Bibliografia}

Boraczyńska, Anna. „Kolekcja Ludmiły Marjańskiej (w zbiorach Biblioteki Publicznej im. dr. Władysława Biegańskiego w Częstochowie)”. In O Ludmile Marjańskiej. Szkice, interpretacje, wspomnienia (134-142), ed. Elżbieta Hurnikowa, Iwona Skrzypczyk-Gałkowska. Częstochowa: Muzeum Częstochowskie, 2015.

${ }^{32}$ Więcej na ten temat Anna Boraczyńska, „Kolekcja Ludmiły Marjańskiej (w zbiorach Biblioteki Publicznej im. dr. Władysława Biegańskiego w Częstochowie)”, in O Ludmile Marjańskiej..., 134-142.

${ }^{33}$ Andrzej Kuśniewicz, Moja historia literatury..., 5. 
Judek, Cecylia. „Ciekawsze rękopiśmienne dedykacje autorskie w księgozbiorze Marii i Stefana Flukowskich”, Bibliotekarz Zachodniopomorski, no. 2/3 (1984): 74-83.

Judek, Cecylia. „Jerzy Liebert i Maria Leszczyńska. Liebertiana w Książnicy Pomorskiej w Szczecinie", Pogranicza, no. 6 (1999): 60-64.

Judek, Cecylia. „Zbiory specjalne”. In Od Stadtbibliothek do Ksiażnicy Pomorskiej 1905-2005, ed. Hanna Niedbał et al. Szczecin: Książnica Pomorska, 2005, 87-120.

Judek, Cecylia. „Przyjaźnie Stefana Flukowskiego”. In Stefan Flukowski i kult nowoczesności, ed. Jerzy Madejski et Beata M. Wolska. Szczecin: Książnica Pomorska, 2015, 45-49.

Kownacka, Barbara M. „Dedykacje w księgozbiorze Stefana i Marii Flukowskich”. In Stefan Flukowski i kult nowoczesności, ed. Jerzy Madejski et Beata M. Wolska. Szczecin: Książnica Pomorska, 2015, 69-90.

„Kronika działalności bibliotek i Stowarzyszenia Bibliotekarzy Polskich”, Bibliotekarz Zachodniopomorski, no. 4 (1975): 83-84.

Kuśniewicz, Andrzej. Moja historia literatury. Warszawa: Państwowy Instytut Wydawniczy, 1980.

Liskowacka, Jolanta. „«...uwierzyliśmy zbyt łatwo, że piękno nie ocala...». Zbigniew Herbert w Książnicy Pomorskiej”. Bibliotekarz Zachodniopomorski, no. 2/3 (2002): 66-75.

Liskowacka, Jolanta. „Księgozbiór Ludmiły Marjańskiej (w zbiorach Książnicy Pomorskiej w Szczecinie)”. In O Ludmile Marjańskiej. Szkice, interpretacje, wspomnienia. Częstochowa: Muzeum Częstochowskie, 2015, 143-155.

Podgajna, Ewa. „Maszyna, listy i książki: pamiątki po Andrzeju Kuśniewiczu w Szczecinie". Gazeta Wyborcza, 12.03.2003: 4.

Szymańska, Kazimiera Zdzisława. Muzea literackie w Polsce (64-66). Częstochowa: Wydawnictwo WSP, 1995.

Torchała, Joanna, ed. Xawery Dunikowski. Szczecin: Książnica Pomorska, 2000.

Zwilnian-Grabowski, Tadeusz et Cecylia Judek. „Dwugłos o Zbigniewie Herbercie”. Bibliotekarz Zachodniopomorski, no. 3 (1998): 42-45.

Rękopisy niepublikowane

Akt przekazania (1981). „Akt przekazania Bibliotece Głównej im. Stanisława Staszica w Szczecinie zbiorów po Stefanie i Marii Flukowskich przez Halinę Leszczyńską". In Teka zagadnieniowa „Sala Stefana Flukowskiego”. Książnica Pomorska w Szczecinie.

Archiwum Herberta (post 1992). Archiwum Zbigniewa Herberta. Książnica Pomorska w Szczecinie, sygn. Inwakc. 1942, 2728, 2949.

Archiwum Kuśniewicza (post 2003). Archiwum Andrzeja Kuśniewicza. Książnica Pomorska w Szczecinie, sygn. Inwakc. 3061-3066.

Archiwum Marjańskiej (post 2003). Archiwum Ludmity Marjańskiej. Książnica Pomorska w Szczecinie, sygn. Inwakc. 3088, 3164, 3458.

List Flukowskiej do Najdowskiego (ca 1976). „List Marii Flukowskiej do I sekretarza KW PZPR Zygmunta Najdowskiego”. In Archiwum Marii i Stefana Flukowskich. Książnica Pomorska w Szczecinie, sygn. Inwakc. 2133. 
List Herberta do Arsoby (1992). „List Zbigniewa Herberta do Barbary Arsoby”. In Materiały związane z przekazaniem daru Zbigniewa Herberta dla Książnicy Szczecińskiej. Książnica Pomorska w Szczecinie, sygn. Inwakc. 1944, k. 1.

List Herberta do Krzywickiego (1997). „List Zbigniewa Herberta do Stanisława Krzywickiego". In Materiały związane z przekazaniem daru Zbigniewa Herberta dla Ksiażnicy Szczecińskiej. Książnica Pomorska w Szczecinie, sygn. Inwakc. 1944, k. 13.

List Krzywickiego do Sonika (1992). „List Stanisława Krzywickiego do Bogusława Sonika”. In Materiały zwiąane z przekazaniem daru Zbigniewa Herberta dla Książnicy Szczecińskiej. Książnica Pomorska w Szczecinie, sygn. Inwakc. 1944, k. 3.

List Marjańskiej do Krzywickiego (2003). „List Ludmiły Marjańskiej do Stanisława Krzywickiego z 7.08.2003”. In Materiały dotyczące księgozbioru Marjańskiej. Książnica Pomorska w Szczecinie.

Pismo Flukowskiej (1976). „Pismo Marii Flukowskiej do Stanisława Krzywickiego z dn. 25.09.1976”. In Teka zagadnieniowa „Sala Stefana Flukowskiego”. Książnica Pomorska w Szczecinie.

Pismo Krupy (1980). „Pismo Józefa Krupy o sygn. M.R.B./0/40/1980 z dn. 28.10.1980”. In Teka zagadnieniowa „Sala Stefana Flukowskiego”. Książnica Pomorska w Szczecinie.

Pismo Sawaściuka (1981). „Pismo Juliana Sawaściuka o sygn. SAiO-IX-415-18/81 z dn. 22.05.1981”. In Teka zagadnieniowa „Sala Stefana Flukowskiego”. Książnica Pomorska w Szczecinie.

Telegram Herberta (1993). „Telegram od Zbigniewa Herberta”. In Materiały związne z przekazaniem daru Zbigniewa Herberta dla Książnicy Szczecińskiej. Książnica Pomorska w Szczecinie, sygn. Inwakc. 1944, k. 10.

Testament Witkiewiczowej (ante 1969). „Testament Jadwigi Witkiewiczowej”. In Archiwum Marii i Stefana Flukowskich. Książnica Pomorska w Szczecinie, sygn. Inwakc. 824, k. 1 . 